\title{
CONTACT AND GUSTATORY EFFECTS OF SPINOSAD ON THE SURVIVABILITY OF SITOPHILUS ORYZAE L. (COLEOPTERA: CURCULIONIDAE) IN WHEAT
}

\author{
Umme Habiba, W Islam* and Selina Parween ${ }^{1}$ \\ Institute of Biological Sciences, University of Rajshahi, \\ Rajshahi-6205, Bangladesh
}

\begin{abstract}
The present study was planned to evaluate the effect of spinosad on the survivability and development of Sitophilus oryzae on four wheat varieties viz., BARI-26, BARI-28, Shatabdi-21 and Prodip-24. Three doses in three replications for spinosad were applied to four wheat varieties. Spinosad concentrations significantly increased the total developmental period compared to the control in a dose-dependent manner on four wheat varieties. The highest developmental period took $41.67 \pm 0.33$ days to become adult was recorded in S-21 at $0.0003 \mu \mathrm{l} / \mathrm{g}$ of spinosad in $F_{1}$. All adults of $F_{1}$ did not reach in $F_{2}$ because surprisingly all adults died after emergence. So, no developmental period was found in S-2 $1(0.00 \pm 0.00)$ and B-28 $(0.00 \pm 0.00)$ days at $0.0003 \mu \mathrm{l} / \mathrm{g}$ spinosad in $\mathrm{F}_{2}$. On the other hand, five mated females were released on the treated wheat with different concentrations of spinosad for 10 - 15 days; then they were removed. Treated wheat was checked for up to 30 to 60 days and observed the progeny for two successive generations (1st and 2nd). Each combination of insect species, insecticide rate, and exposure duration were replicated three times. Among four wheat varieties, the lowest adult emergence was recorded as $08.00 \pm 0.58$ in $F_{1}$ and totally controlled in $F_{2}$ generation in S-21 variety at $0.0003 \mu \mathrm{l} / \mathrm{g}$. Spinosad concentrations significantly increased the total developmental period compared to the control in a dosedependent manner on four wheat varieties.
\end{abstract}

Key words: Contact and gustatory effects, spinosad, developmental period, Sitophilus oryzae

\section{INTRODUCTION}

Wheat (Triticum aestivum L.) is an important staple food used in many parts of the world and is a moderately salinity tolerance crop. Wheat grains are vulnerable to many insects in storage and insecticides are used as a most effective measure for protecting stored products from pest infestation. The rice weevil, Sitophilus oryzae L. (Coleoptera: Curculionidae) has been reported as one of the severe pests of rice, sorghum, wheat, barley and other cereal grains and their products (Baloch 1992), is cosmopolitan in nature and causes intense losses in rice, maize, barley, wheat and other vegetation quantitatively and qualitatively throughout the world (Arannilewa et al. 2002, Tefera 2012). Both

*Author for correspondence: <mwislam18@gmail.com>. 1Department of Zoology, University of Rajshahi, Bangladesh.

@2019 Zoological Society of Bangladesh DOI: https://doi.org/10.3329/bjz.v47i2.44336 
the adults and larvae fed on the kernels leaving only the outer integument. The whole developmental stages of this pest passed in the grain (Banglapedia 2006, revised 2014). S. oryzae is an internal feeder. It is very harmful pest of stored wheat worldwide (Rees 2004). The larvae of S. oryzae can destroy 25 - 30\% of the wheat kernel that reduces the market cost of wheat (Kadir et al. 2005). True proteins are definitely decreased as the insect feeds on both endosperm and embryo causing quantitative and qualitative damage (Prabhakumary and Sini 2008). Spinosad is an insecticide product from Dow Agro Sciences (Indianapolis, Indiana, USA) based on chemical compounds of a soil bacterium Saccharopolyspora spinosa was discovered in 1985 (Mertz and Yao 1990). This is aerobic, Gram-positive, nonacid-fast actinomycetes with fragmenting mycelium. Spinosad is a mixture of two spinosoid spinosyns A $\left(\mathrm{C}_{42} \mathrm{H}_{67} \mathrm{NO}_{16}\right)$ is the major component and $\mathrm{D}\left(\mathrm{C}_{41} \mathrm{H}_{65} \mathrm{NO}_{16}\right)$ is the minor component, present in an approximately $85: 15 \%$ ratio in the final product (Mertz and Yao 1990, Sparks et al. 1999). It is a naturally derived bio rational insecticide with an environmentally favorable toxicity profile (Bond et al. 2004). Spinosad degrades very quickly on soil surfaces by photolysis and below the soil surface by soil microorganisms (Saunders and Bret 1997, Thompson et al. 2000). It is classified as an environmentally and toxicologically reduced risk material by the U.S. Environmental Protection Agency (Cleveland et al. 2001). Its using rate is $1 \mathrm{mg}$ (AI) $/ \mathrm{kg}$ of grain, and the tolerance level was established at $1.5 \mathrm{mg}(\mathrm{AI}) / \mathrm{kg}$ (Bruggink 2005).

Spinosad efficacy was observed in layer treated wheat against five stored product pest including S. oryzae (Athanassiou et al. 2009). The effect of short exposures to spinosad-treated wheat or maize was also evaluated against adults of four stored-product insect species including $S$. oryzae and in spinosad-treated grain progeny production of $S$. oryzae and $R$. dominica is directly related to the speed of death of adults (Athanassiou et al. 2010). Getchell and Subramanyam (2008) found the instantaneous mortality of S. oryzae adults on wheat, maize, and sorghum treated with spinosad at various exposure intervals.

The spinosad's overall performance against stored insect pests and their offspring production relies upon on several factors like formulation, commodity, temperature, application rate and insect species (Athanassiou et al. 2008a, b, 2009, 2010, 2011, Vayias et al. 2010). Therefore, the present investigation characterizes the effectiveness of spinosad against $S$. oryzae adult mortality and the survivability of adult's emergence and its developmental time in economically important stored-product grain insect, S. oryzae in two successive generations on four wheat varieties. 


\section{MATERIAL AND METHODS}

In the present bioassay method spinosad were investigated against adults of Sitophilus oryzae by dietary exposure termed Treated Food Method (TEM) (Talukder and Howse 1994).

S. oryzae was obtained from the stock culture without any exposure to insecticides, maintained in the control temperature room, at Entomology and Insect Biotechnology Laboratory, Institute of Biological Sciences, University of Rajshahi, Bangladesh. Untreated and infestation free of wheat varieties viz., BARI-26, BARI-28, Prodip-24 and Shatabdi-21 were used.

Mass cultures were maintained in plastic containers (2.5 litre). The whole culture procedure was maintained in a control temperature room at $30 \pm 1{ }^{\circ} \mathrm{C}$ and $70 \pm 5 \% \mathrm{RH}$. About 250 adults of $\mathrm{S}$. oryzae were placed in the plastic container with $250 \mathrm{~g}$ of whole wheat grain for 10 - 15 days, then they were removed and placed on fresh grains to get a new progeny and avoid generation overlapping. The whole process was repeated several times to ensure $100 \%$ adult collection from the old culture medium to obtain homogenous generations throughout the experiment. Mouth of the container was covered with muslin cloth using a rubber band, to prevent the possible contamination and escape of insects (Mondal and Parween 1997).

Preparation of food medium for mass-culture: Whole wheat grains were used as the food for the weevils. Wheat grains were collected from the local market, Shaheb Bazar, Rajshahi. After washing in water, the wheat was sun-dried and finally sterilized in an oven at $60^{\circ} \mathrm{C}$ for $6 \mathrm{hrs}$. Sterilized wheat grains kept for 15 days to allow its moisture content $(13.5 \%)$ to equilibrate with that of the environments. Sterilized wheat was used as food for mass-culture.

Preparation of food medium for experiments: Four kinds of wheat grains (B26, B-28, P-24 and S-21) were collected from the Wheat Research Institute, Shampur, Rajshahi, Bangladesh. These grains were washed and cleaned by sieving through 500 micrometer aperture sieve and sterilized in an oven at $60^{\circ} \mathrm{C}$ for $6 \mathrm{hrs}$. Then grains were kept in plastic containers (3 liters) that were cleaned before and use throughout the experimental period for S. oryzae.

Collection of weevils: After tremble the container some of the grain was taken on the working table with the help of a medium sized spoon. The adults were collected using a camel hair brush and placed in treatment.

Source of spinosad: Spinosad is light grey to white in colour with slight odour stale water. About 500ml of spinosad (PRN- MAPP-12054, cafno 20012019, Lot No-3068404) was obtained from Dow Agro Sciences, UK. Concentration of spinosad was $120 \mathrm{~g}$ spinosad/litre. Spinosad $0.0018 \mu \mathrm{l}$ was obtained in a glass 
vial by the help of micropipette and added $6 \mathrm{ml}$ distilled water properly by using $2 \mathrm{ml}$ syringe and $0.0003,0.00015$ and $0.000075 \mu \mathrm{l} / \mathrm{g}$ were prepared by serial dilution.

Bioassays: Wheat grains $1 \mathrm{~g}$ of each variety of wheat was soaked in different concentrations of spinosad separately and then dried at room temperature for $24 \mathrm{hrs}$ in a $6 \mathrm{~cm}$ glass Petri dish.

From mass culture five mated females were released on the treated wheat with different concentrations of spinosad for 10 - 15 days; then they were removed. The Petri dish was covered and the medium containing eggs and larvae were placed in the control room temperature until adult emergence. Treated wheat was checked for up to 30 - 60 days and observed the progeny for two successive generations ( 1 st and 2 nd). After every 10 days, newly treated fresh wheat was added with it. A similar set of experiment was carried out on wheat soaked with distilled water only, as a control batch. The room temperature was maintained at $30 \pm 1^{\circ} \mathrm{C}$ with $75 \% \mathrm{RH}$ in the control temperature throughout the study period. As, S. oryzae is an internal feeder so, only adults production for this species was recorded for $F_{1}$ and $F_{2}$. Adults unable to move when prodded gently with a hair brush were considered dead. The number of progeny for $S$. oryzae was based on all visible live adults found in wheat. Each combination of insect species, insecticide rate, and exposure duration was replicated three times, and each replicate was treated separately. Adult emergence and adult survivability of $S$. oryzae was determined to untreated and treated wheat with spinosad concentration for two successive generations.

Data collection and statistical analysis: Data were subjected to analysis of variance using SPSS-20 version. Means comparisons were performed by Turkey's tests $(p<0.05)$. The percent reduction of adult emergence in treatments compared to control (PRC) was calculated by using the formula provided by Mian and Mulla (1982a) as follows:

$$
\text { PRC }=1-\quad \frac{\text { Average no. of adult emerged (treatment) }}{\text { Average no. of adult emerged (control) }}: 100
$$

The mortality data were corrected using Abbott's formula (Abbott 1925) as follows:

$$
\frac{\mathrm{P}_{\mathrm{o}}-\mathrm{P}_{\mathrm{c}}}{100-\mathrm{P}_{\mathrm{c}}} \mathrm{P}_{\mathrm{t}} \times 100
$$




\section{RESULTS AND DISCUSSION}

Effect on adult recovery/emergence: Effect of spinosad on the adult emergence of S. oryzae on four wheat varieties in $\mathrm{F}_{1}$ and $\mathrm{F}_{2}$ are presented in Table 1 . No mortality was found in the untreated (control) wheat. In control, the adult emergence ranged from $56.33 \pm 1.86$ to $70.00 \pm 2.89$ in $\mathrm{F}_{1}$ whereas $145.00 \pm 3.00$ to 165.33 $\pm 2.91 \mathrm{in} \mathrm{F}_{2}$. In treated the adult emergence ranged from $08.00 \pm 0.58$ to $49.33 \pm$ 2.33 in $F_{1}$ whereas $0.00 \pm 0.00$ to $29.67 \pm 2.60$ in $F_{2}$. Among four wheat varieties, the lowest adult emergence was recorded as $08.00 \pm 0.58$ in $F_{1}$ generation and totally controlled in $\mathrm{F}_{2}$ in $\mathrm{S}-21$ variety at $0.0003 \mu \mathrm{l} / \mathrm{g}$ concentration. The highest PRC value was $85.80 \%$ noted in S-21 variety in $\mathrm{F}_{1}$, $100 \%$ (extremely controlled) observed in S-21 and B-28 varieties treated with $0.0003 \mu \mathrm{l} / \mathrm{g}$ concentration.

ANOVA showed that highly significant differences among wheat varieties in $\mathrm{F}_{1}(\mathrm{~F}=40.88$, df $=3, \mathrm{p}<0.001)$ and in $\mathrm{F}_{2}(\mathrm{~F}=23.26$, df $=3, \mathrm{p}<0.001)$ generation and concentrations in $\mathrm{F}_{1}(\mathrm{~F}=403.09$, df=3, $\mathrm{p}<0.001)$ and in $\mathrm{F}_{2}(\mathrm{~F}=$ 5746.87, $\mathrm{df}=3, \mathrm{P}<0.001)$. The relation between varieties and concentrations was not significant in $F_{1}(F=1.04, d f=9, p>0.05)$ and significant in $F_{2}(F=$ 3.31, $\mathrm{df}=9, \mathrm{p}<0.01$ ) generation (Table 1$)$.

Effect on total developmental period: Dietary treatment of S. oryzae with spinosad concentrations significantly increased the total developmental period compared to the control (Table 2) in a dose-dependent manner on four wheat varieties. In $F_{1}$, developmental period ranged from $29.67 \pm 0.33$ to $31.33 \pm 0.33$ days in control and $31.00 \pm 0.58$ to $41.67 \pm 0.33$ days in treatment whereas, the range of developmental period was from $29.33 \pm 0.67$ to $31.67 \pm 0.33$ days in control and $0.00 \pm 0.00$ to $45.67 \pm 0.33$ days in treatment in $F_{2}$. The highest developmental period was $41.67 \pm 0.33$ days to become adult was recorded in S21 at $0.0003 \mu \mathrm{l} / \mathrm{g}$ of spinosad compared with the control and rest of other concentrations in $F_{1}$. All adults of $F_{1}$ did not reach in a $F_{2}$ because surprisingly they died after emerge. So, no developmental period was recorded in S-21 0.00 $\pm 0.00)$ and B-28 (0.00 \pm 0.00$)$ days at $0.0003 \mu \mathrm{l} / \mathrm{g}$ spinosad in $\mathrm{F}_{2}$.

Table 2 showed significant effect among varieties in $\mathrm{F}_{1}(\mathrm{~F}=22.04$, $\mathrm{df}=3, \mathrm{p}<$ $0.001)$ and in $\mathrm{F}_{2}(\mathrm{~F}=534.67, \mathrm{df}=3, \mathrm{p}<0.001)$ generation and concentrations $(\mathrm{F}$ $=311.84$, $\mathrm{df}=3, \mathrm{p}<0.001)$ and $(\mathrm{F}=1108.78, \mathrm{df}=3, \mathrm{p}<0.001)$ in $\mathrm{F}_{2}$. But, interactions between varieties and concentrations was not significant in $F_{1}(F=$ 1.23, $\mathrm{df}=9, \mathrm{p}>0.05)$ and highly significant in $\mathrm{F}_{2}(\mathrm{~F}=769.88, \mathrm{df}=9, \mathrm{p}<0.001)$ generations. 
Effect on total developmental period: Dietary treatment of $S$. oryzae with spinosad concentrations significantly increased the total developmental period compared to the control (Table 2) in a dose-dependent manner on four wheat varieties. In $F_{1}$, developmental period ranged from $29.67 \pm 0.33$ to $31.33 \pm 0.33$ days in control and $31.00 \pm 0.58$ to $41.67 \pm 0.33$ days in treatment whereas, the range of developmental period was from $29.33 \pm 0.67$ to $31.67 \pm 0.33$ days in control and $0.00 \pm 0.00$ to $45.67 \pm 0.33$ days in treatment in $F_{2}$. The highest developmental period $41.67 \pm 0.33$ days to become adult was recorded in S-21 at $0.0003 \mu \mathrm{l} / \mathrm{g}$ of spinosad compared with the control and rest of other concentrations in $F_{1}$. All adults of $F_{1}$ did not reach in a $F_{2}$ because surprisingly all adults were died after emerge. So, no developmental period was found in S$21(0.00 \pm 0.00)$ and B-28 (0.00 \pm 0.00$)$ days at $0.0003 \mu \mathrm{l} / \mathrm{g}$ spinosad in $\mathrm{F}_{2}$.

Table 1. Effect of spinosad on survivability of adult emergence of $S$. oryzae in $F_{1}$ and $F_{2}$ generations

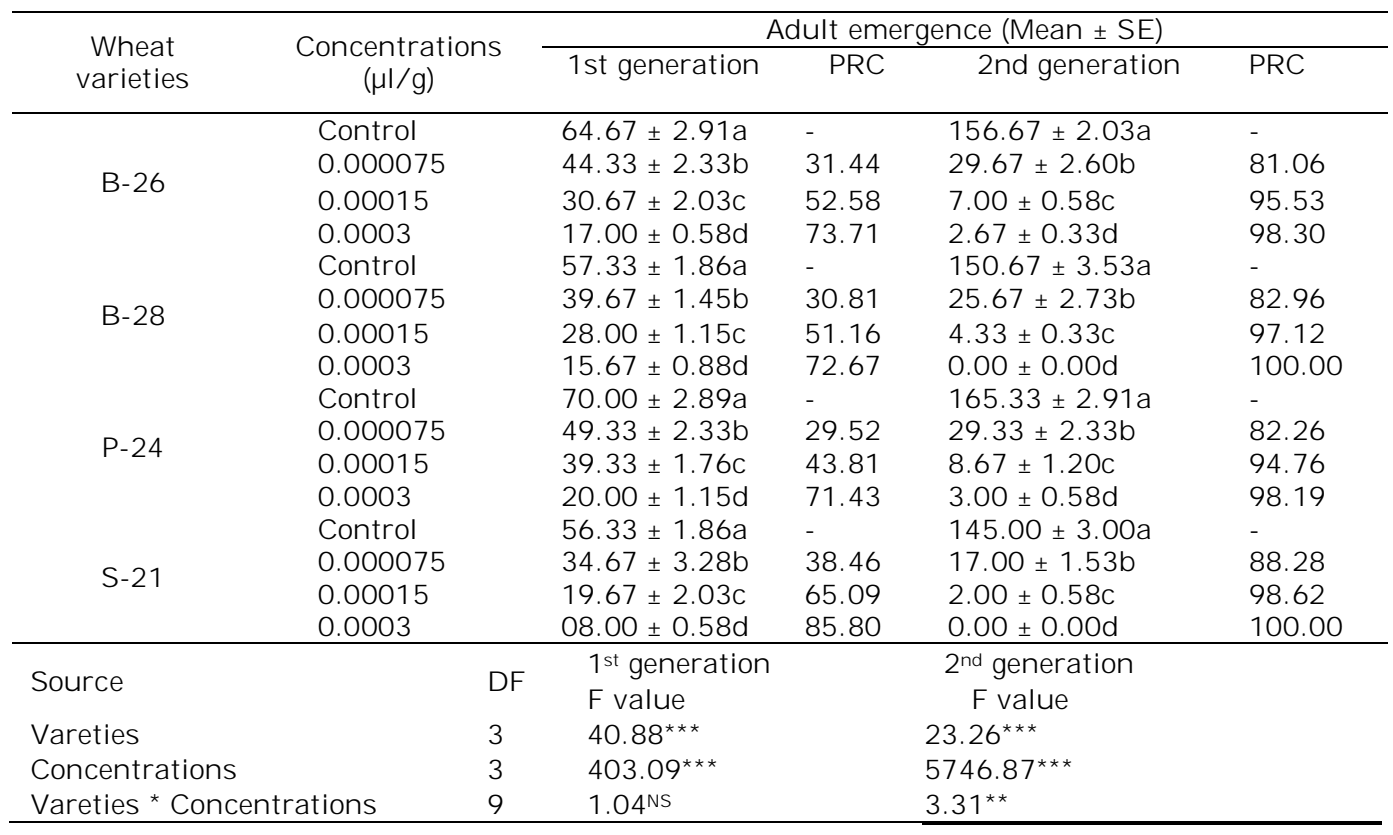

Column means with same letter do not differ significantly from each other within varieties at $0.05 \%$ level (Tukey's test). ${ }^{* * *}$ Significant at $\mathrm{p}<0.001,{ }^{* *}$ Significant at $\mathrm{p}<0.01, \mathrm{NS}=$ Non significant.

Table 2 showed that highly significant effect found among varieties $(\mathrm{F}=$ 22.04, df $=3, \mathrm{p}<0.001)$ in $\mathrm{F}_{1}$ and $(\mathrm{F}=534.67, \mathrm{df}=3, \mathrm{p}<0.001)$ in $\mathrm{F}_{2}$ and concentrations $(\mathrm{F}=311.84$, $\mathrm{df}=3, \mathrm{p}<0.001)$ in $\mathrm{F}_{1}$ and $(\mathrm{F}=1108.78, \mathrm{df}=3, \mathrm{p}<$ $0.001)$ in $F_{2}$. But, interactions between varieties and concentrations was non- 
significant $(\mathrm{F}=1.23, \mathrm{df}=9, \mathrm{p}>0.05)$ in $\mathrm{F}_{1}$ and highly significant $(\mathrm{F}=769.88 \mathrm{df}$ $=9, \mathrm{p}<0.001)$ in $\mathrm{F}_{2}$.

Table 2. Effect of spinosad on developmental period of $S$. oryzae in $F_{1}$ and $F_{2}$ generations

\begin{tabular}{|c|c|c|c|c|}
\hline \multirow{2}{*}{$\begin{array}{l}\text { Wheat } \\
\text { varieties }\end{array}$} & \multirow{2}{*}{\multicolumn{2}{|c|}{$\begin{array}{c}\text { Concentrations } \\
(\mu \mathrm{l} / \mathrm{g})\end{array}$}} & \multicolumn{2}{|c|}{ Developmental period (Mean \pm SE) } \\
\hline & & & 1st generation & 2nd generation \\
\hline \multirow{4}{*}{ B-26 } & Control & & $30.00 \pm 0.58 \mathrm{~d}$ & $30.33 \pm 0.33 c$ \\
\hline & 0.000075 & & $31.33 \pm 0.67 \mathrm{c}$ & $33.67 \pm 0.67 b$ \\
\hline & 0.00015 & & $35.67 \pm 0.33 b$ & $41.33 \pm 0.67 a$ \\
\hline & 0.0003 & & $39.33 \pm 0.67 \mathrm{a}$ & $45.67 \pm 0.33 d$ \\
\hline \multirow{4}{*}{ B-28 } & Control & & $30.33 \pm 0.33 d$ & $30.67 \pm 0.33 c$ \\
\hline & 0.000075 & & $32.67 \pm 0.33 c$ & $34.67 \pm 0.33 b$ \\
\hline & 0.00015 & & $36.33 \pm 0.33 b$ & $42.67 \pm 0.33 a$ \\
\hline & 0.0003 & & $40.33 \pm 0.33 a$ & $0.00 \pm 0.00 \mathrm{~d}$ \\
\hline \multirow{4}{*}{$\mathrm{P}-24$} & Control & & $29.67 \pm 0.33 d$ & $29.33 \pm 0.67 \mathrm{c}$ \\
\hline & 0.000075 & & $31.00 \pm 0.58 c$ & $33.33 \pm 0.33 b$ \\
\hline & 0.00015 & & $33.33 \pm 0.33 b$ & $39.33 \pm 0.67 \mathrm{a}$ \\
\hline & 0.0003 & & $38.67 \pm 0.67 a$ & $43.67 \pm 0.88 d$ \\
\hline \multirow{4}{*}{ S-211 } & Contro & & $31.33 \pm 0.33 \mathrm{~d}$ & $31.67 \pm 0.33 c$ \\
\hline & 0.000075 & & $33.00 \pm 0.58 c$ & $36.00 \pm 0.58 b$ \\
\hline & 0.00015 & & $37.33 \pm 0.67 b$ & $43.67 \pm 0.33 a$ \\
\hline & 0.0003 & & $41.67 \pm 0.33 a$ & $0.00 \pm 0.00 \mathrm{~d}$ \\
\hline \multirow{2}{*}{ Source } & & DF & 1st generation & 2nd generation \\
\hline & & DT & F value & $F$ value \\
\hline \multicolumn{2}{|c|}{ Wheat vareties } & 3 & $22.04 * * *$ & $534.67^{* * *}$ \\
\hline \multicolumn{2}{|c|}{ Concentrations } & 3 & $311.84^{* * *}$ & $1108.78^{* * *}$ \\
\hline \multicolumn{2}{|c|}{ Wheat vareties *Concentrations } & 9 & $1.23^{\mathrm{NS}}$ & $769.88^{* * *}$ \\
\hline
\end{tabular}

In a column means with same letter do not vary significantly within varieties at $\mathrm{p}<0.05$ level (Tukey's test). ${ }^{* * *}$ Significant at $\mathrm{p}<0.001, \mathrm{NS}=$ Non Significant.

The results of the present study indicate that there was a significant impact of spinosad on the adult emergence and total developmental period of S. oryzae in wheat varieties. Since spinosad acts as a contact insecticide, the present research assumes that at control room temperature the increased spinosad resulting in increased mortality. From a practical point of view, 0.000075 and $0.00015 \mu \mathrm{l} / \mathrm{g}$ of spinosad gave decreasing adult emergence levels. Consequently, spinosad at $0.0003 \mu \mathrm{l} / \mathrm{g}$ was higher concentration and can satisfactorily control the adult emergence of $S$. oryzae in successive two generations.

It was showed that insecticidal efficacy often vary depending upon the particular insecticide and the commodity that is treated. Spinetoram (group of spynosyn) efficacy against $S$. oryzae was notably increasing from the size of the treated layer, and elevated length drastically increased mortality and reduced progeny production. Mortality was high only on totally treated wheat for layer 
treated wheat ranged between 32 and $72 \%$. Mortality became substantially lower on rice than wheat which suggests that spinetoram became much less effective on rice than on wheat (Vassilakos and Athanassiou 2012). The present investigation revealed that spinosad at $0.0003 \mu \mathrm{l} / \mathrm{g}$ concentration significantly gave the lowest percentage $(08.00 \pm 0.58 \%)$ of adult emergence of $S$. oryzae in S-21 in $\mathrm{F}_{1}$ and absolutely controlled the adult emergence in S-21 and B-28 wheat varieties in $\mathrm{F}_{2}$ compared with the control and rest of other concentrations.

The efficacy of spinosad in the present study was more or less similar with the findings of Huang et al. (2007) who revealed that spinosad at $1 \mathrm{mg}(\mathrm{AI}) / \mathrm{kg}$ provided $100 \%$ reduction of egg-to-adult emergence of Sitotroga cerealella. Minimal presence of spinosad on wheat had some lethal effect on parental S. oryzae. On the other hand, the lower percentage of treated kernels significantly increased progeny production of $S$. oryzae for wheat. The complete control of adult $S$. zeama and progeny production on maize with two liquid formulations is in agreement with Huang and Subramanyam (2007), who mentioned similar consequences with a commercial liquid formulation of spinosad used on field crops (SpinTor 2SC). The present finding is in agreement with the above results where complete control of adult emergence of $S$. oryzae was observed in varieties S-21 and B-28 in $\mathrm{F}_{2}$. Andric et al. (2019) reported that all doses of spinetoram achieved high mortality (96 - 100\%) of S. granarius on both wheat varieties, viz, variety with high (HVWG) and another with low (LVWG) endosperm vitreousness. While high mortality of S. oryzae (97 - 100\%) and both populations of S. zeama is (93 - 100\%) was achieved using $1-2 \mathrm{mg}$ doses on the HVWG and $2 \mathrm{mg}$ dose on the LVWG variety after 14 days.

In the present work, there was significant increase in time taken for development at all concentration of spinosad in comparison with the control. Developmental periods was increased in all wheat varieties at $0.0003 \mu \mathrm{l} / \mathrm{g}$ of spinosad and no developmental period was observed in S-21 and B-28 wheat varieties in $\mathrm{F}_{2}$ at $0.0003 \mu \mathrm{l} / \mathrm{g}$.

The present investigation revealed that spinosad at $0.0003 \mu \mathrm{l} / \mathrm{g}$ concentration significantly gave the lowest percentage $(08.00 \pm 0.58 \%)$ of adult emergence of $S$. oryzae in S-21 in $F_{1}$ and absolutely controlled the adult emergence in S-21 and B-28 wheat varieties in $\mathrm{F}_{2}$ compared with the control and rest of other concentrations.

The results of the present study indicate that there was a significant impact of spinosad on the adult emergence and total developmental period of S. oryzae in wheat varieties. From a practical point of view, 0.000075 and $0.00015 \mu \mathrm{l} / \mathrm{g}$ of spinosad gave decreasing adult emergence levels. Consequently, spinosad at 
$0.0003 \mu \mathrm{l} / \mathrm{g}$ was higher concentration and can satisfactorily control of adult emergence of $S$. oryzae in successive two generations.

\section{LITERATURE CITED}

ABBOT, W. 1925. A method for computing the effectiveness of an insecticide. J. Econ. Entomol. 18: 265-267.

ANDRIC, G., KLJAJIC, P., GOLIC, M. P., TRDAN, S., BOHINC, T. and SOLAROV, M.B. 2019. Effectiveness of spinosad and spinetoram against three Sitophilus species: Influence of wheat endosperm vitreousness. J. Stored Prod. Res. 83: 209-217.

ARANNILEWA, S.T., EKRAKENE, T. and AKINNEY, J. O. 2002. Laboratory evaluation of four medicinal plants as protectants against the maize weevil, Sitophilus zeamais (Mots). African J. Biotech. 5: 2032-2036.

ATHANASSIOU, C.G., ARTHUR, F.H. and THRONE, J.E. 2009. Efficacy of spinosad in layer treated wheat against five stored-product insect species. J. Stored Prod. Res. 45: 236-240.

ATHANASSIOU, C.G., ARTHUR, F.H. and THRONE, J.E. 2010. Effects of short exposures to spinosad-treated wheat or maize on four stored-grain insects. J. Econ. Entomol. 103: 197-202.

ATHANASSIOU, C.G., ARTHUR, F. H., KAVALLIERATOS, N. G. and THORNE, J. E. 2011 . Efficacy of spinosad and methoprene, applied alone or in combination, against six stored product insect species. J. Pest Sci. 84: 61-67.

ATHANASSIOU, C.G., KAVALLIERATOS, N.G. and CHINTZOGLOU GJ 2008a. Effectiveness of spinosad dust against different European populations of the confused flour beetle, Tribolium confusum Jacquelindu Val. J. Stored Prod. Res. 44: 47-51.

ATHANASSION, C.G., KAVAlLIERATOS, N.G., YIATliS, A.E., VAVIAS, B.J., MAVROTAS, C.S. and TOMANOVIC, Z. 2008b. Influence of temperature and humidity on the efficacy of spinosad against four stored-grain beetle species. J. Insect Sci. 8: 1-9.

BALOCH, U.K. 1992. Integrated Pest Management in Food Grains.Food and Agriculture Organization of the United Nations and Pakistan Agricultural Research Council, Islamabad, Pakistan. pp. 117 .

Banglapedia 2006. Banglapedia National Encyclopedia of Bangladesh. http://www.banglapedia.org/httpdocs/HT/W_0053. htm (modified 23 November 2014).

BOND, J. G., MARINA, C. F. and WILLIAMS, T. 2004. The naturally derived insecticide spinosad is highly toxic to Aedes and Anopheles mosquito larvae. Med. Vet. Entomol.18: 50-56.

BRUGGINK, B. 2005. USEPA registers spinosad for stored grain protection. Dow AgroSciences LLC. Available: http://www.dowagro.com/usag/resource/smgrains /20050119a.htm.

CLEVELAND, C.B., MAYES, M.A. and CRYER, S.A. 2001.An ecological risk assessment for spinosad use on cotton. Pest Manage. Sci. 58: 70-84.

GETCHELL, A.I. and SUBRAMANYAM, B. 2008. Immediate and delayed mortality of Rhyzopertha dominica (Coleoptera: Bostrychidae) and Sitophilus oryzae (Coleoptera: Curculionidae) adults exposed to spinosad-treated grain. J. Econ. Entomol. 101: 1022-1027.

HUANG, F. and SUBRAMANYAM, B. 2007. Effectiveness of spinosad against seven major storedgrain insects on corn. Insect Sci.14: 225-230. J. Compilation @ Institute of Zoology, Chinese Academy of Sciences.

KADIR, S., BHADRIRAJU, S., RAMASWAMY, S., REED, C. and ARTHUR, F. 2005. Crop profile for on farm stored wheat in Kansas. 
MERTZ, F.P. and YAO, R.C. 1990. Saccharopolyspora spinosa sp. nov. isolated from soil collected in a sugar mill rum still. Int. J. Sys. Bacteriology 40: 34-39.

MIAN, L.S. and MULLA, N.S. 1982a. Biological activity of IGRs against flour stored product coleopterans. J. Econ. Entomol. 75: 80-85.

MONDAL, K. and PARWEEN, S. 1997. Laboratory culturing of flour beetles, Tribolium species. Tribolium Inf. Bull. 37: 153-162.

PRABHAKUMARY, C. and SINI, A. 2008. Biochemical changes of stored cashew kernels due to infestation by Tribolium castaneum (Herbst). Curr. Biotica 2: 244-248.

REES, D. 2004. Insects of stored products. CSIRO Publishing, Collingwood, Australia.

SAUNDERS, D.G. and BRET, B.L. 1997. Fate of spinosad in the environment. Down to Earth 52 : 14-20.

SPARKS, T.C., THOMPSON, G.D., KIRST, H.A., HERTLEIN, M.B., MYNDERSE, J.S., TURNER, J.R. and WORDEN, T. V. 1999. Fermentation-derived insect control agents. In: Hall F Rand Menn $\mathrm{J} J$ (Eds.), Biopeticides: Use and Delivery. Humana Press, Totowa, 171-188.

TALUKDER, F.A. and HOWSE, P.E. 1994. Efficacy of pithraj (Aphanamixis polystachya) seed extracts against stored-product pests. Proc. 6th Int. Working Conf. on stored-product Protection 2: 848852. Canberra, Australia.

TEFERA, T. 2012. Post-harvest losses in Africa maize in face of increasing food shortage. Food Sec.4: 267-277.

THOMPSON, G.D., DUTTON, R. and SPARKS, T.C. 2000. Spinosad - A case study: an example from a natural products discovery programme. Pest Manage. Sci. 56: 696-702.

VASSILAKOS, T.N. and ATHANASSION, C.G. 2012. Effect of uneven distribution of spinetoramtreated wheat and rice on mortality and progeny production of Rhyzopertha dominica (F.), Sitophilus oryzae (L.) and Tribolium confusum Jacquelin du Val. J. Stored Prod. Res. 50: 73-80.

VAYIAS, B.J., ATHANASSIOU, C.G., MILONAS, D.N. and MAVROTAS, C. 2010b. Persistence and efficacy of spinosad on wheat, maize and barley grains against four major stored product pests. Crop Prot. 29: 496-505. 